\title{
E o leitor se tornou um escritor: relações entre letramento literário e a formação do escritor em A menina do sobrado, de Cyro dos Anjos ${ }^{1}$
}

\author{
Hércules Tolêdo Corrêa \\ UNI-BH
}

\section{De leitores e suas leituras}

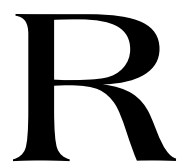

efletir sobre as relações que se estabelecem entre a formação do leitor de literatura e a formação do escritor é o principal objetivo de pesquisa que vem sendo desenvolvida no Centro Universitário de Belo Horizonte - Uni-BH, numa tentativa de articulação entre as áreas de Educação e Literatura. Num primeiro momento, optamos por estabelecer como corpus a narrativa memorialística $A$ menina do sobrado, de Cyro dos Anjos (1906-1994).

\footnotetext{
${ }^{1}$ Registro e agradeço a participação da bolsista de iniciação científica Georgia Roberta de Oliveira Ribeiro, graduanda em Letras no Uni-BH, no desenvolvimento do projeto de pesquisa intitulado Educação, literatura e subjetividade: relações entre o letramento literário e a formação do escritor em obras autobiográficas/memorialísticas de escritores (as) brasileiros (as) do Século XX. Todas as referências a esta obra foram feitas a partir de ANJOS, Cyro dos. A menina do sobrado. (memórias) $2^{\mathrm{a}}$ ed. Rio de Janeiro/Belo Horizonte: Garnier, 1994. (A primeira edição, com este título, é de José Olympio-INL-MEC e data de 1979).
} 
Mineiro de Montes Claros, Cyro dos Anjos teve uma produção literária relativamente pequena: três romances (O amanuense Belmiro, de 1937; Abdias, de 1945, e Montanha, de 1956); um ensaio (A criação literária, de 1954); um livro de poemas (Poemas coronários, de 1964) e um livro de memórias. Este último, publicado em 1979, consiste no acréscimo da parte intitulada "Mocidade, amores" ao conjunto publicado em 1963, com o título de Explorações no tempo, e que passou a chamar a partir de então "Santana do Rio Verde".

Pouco se escreveu e se publicou a respeito de Cyro dos Anjos e de sua obra. Sobre A menina do sobrado, não foi localizado, até o presente momento, nenhum ensaio específico. Conforme Alfredo BOSI (1994:418), sua fortuna crítica consiste de poucos textos, inseridos em notas de críticas a vários escritores e poetas, tais como: Brigada ligeira, de Antonio Candido, 1945; O romance e seus problemas, de Adolfo Casais Monteiro, de 1950; Páginas de crítica, de Eduardo Frieiro, de 1955, Dimensões, de Eduardo Portella, de 1958, e Estudos e notas críticas, de Miécio Tati, de 1958.

Em A menina do sobrado (doravante apenas $A M S$ ) é possível identificar a mediação de diversas instituições e de diferentes sujeitos na formação do leitor, tais como a família (principalmente nas figuras do pai, do primo e da velha empregada); a escola (na figura das professoras primárias); o tio filósofo e seus livros; as leituras de romances de capa-eespada na adolescência; as discussões literárias com os amigos de boemia da Belo Horizonte nos anos vinte do Século XX e o contato com os principais nomes do modernismo mineiro.

Pôde-se perceber, dentre as várias instituições mediadoras da leitura, o papel preponderante da literatura, ela mesma, na formação do leitor e, conseqüentemente, no processo de formação do escritor. A escola, apesar de ter como um de seus principais objetivos a formação de leitores, muitas vezes não tem conseguido esse intento: "por isso, talvez seja urgente que a escola reconfigure hábitos e espaços que levem o estudante a desejar o local silencioso onde seja possível ficar com o livro de sua escolha.", como afirma Maria Nazareth Fonseca (2000), no artigo "Condições de produção da leitura literária", publicado na revista Presença pedagógica. As histórias de leitores que se tornaram célebres principalmente porque de leitores contumazes na infância e na juventude passaram à condição de escritores, como o argentino Jorge Luís Borges e o cubano/italiano Italo Calvino, ou como o francês Marcel Proust, que 
chegou a escrever um pequeno livro intitulado Sobre a leitura, ${ }^{2}$ ou ainda as escritoras brasileiras de livros infantis e juvenis Ana Maria Machado e Marina Colasanti ${ }^{3}$ - mostram-nos pessoas que desde cedo se apaixonaram e se envolveram com o universo livresco, fazendo dele, posteriormente, sua profissão. Esses casos, entretanto, são exceções, se pensamos no número de alunos que, após deixarem a escola, raramente lêem um livro literário, sem contar aqueles que nunca mais retomam a leitura desse tipo de livro. Dados de trabalhos quantitativos como a pesquisa Datafolha, de 1996, a pesquisa Retrato da Leitura no Brasil, de 2001, e a pesquisa INAF - Indicador Nacional de Alfabetismo Funcional, de 2001, atestam isso. ${ }^{4}$

${ }^{2}$ PROUST, 1991. Trata-se de tradução e publicação, em separado, do prefácio que Marcel Proust escreveu para a tradução do livro Sésame et les Lys, de John Ruskin, em 1905.

${ }^{3}$ Marina Colasanti, na verdade, nasceu em Asmara, Etiópia, em 1937, mas veio para o Brasil em 1948. Sua literatura é originalmente produzida em língua portuguesa, daí termos considerado como uma escritora brasileira.

${ }^{4}$ Em pesquisa de opinião realizada pelo Datafolha, em data próxima à realização da 14를 Bienal Internacional do Livro de São Paulo, em 1996, 57\% dos brasileiros entrevistados não haviam lido nenhum livro por lazer ou cultura nos últimos doze meses anteriores à enquete. $33 \%$ haviam lido de 1 a 5 livros por lazer e cultura, $6 \%$ leram de 6 a 10 livros e apenas 4\% leram mais de 10 livros. A média de livros lidos ficou em 2,4 por lazer e cultura; 1 para a escola e 1,2 para o trabalho. Essa pesquisa foi realizada em 11 capitais brasileiras (São Paulo, Rio de Janeiro, Belo Horizonte, Porto Alegre, Curitiba, Florianópolis, Salvador, Recife, Goiânia, Campo Grande e São Luís), com população acima de 16 anos. A pesquisa ainda divulgou outros dados, como os motivos pelos quais os brasileiros não liam mais (a falta de tempo era o motivo alegado pela maioria, 77\%), os escritores e os tipos de livros preferidos dos 8.766 entrevistados. A pesquisa Retrato da Leitura no Brasil mostra que, para o brasileiro, a leitura de livros tem um valor social, mas ler não constitui um prazer. Os principais resultados da pesquisa foram: apesar de $62 \%$ das pessoas entrevistadas declararem ter a leitura como hábito, somente 30\% tinham lido um livro nos três meses anteriores à enquete. Apenas $14 \%$ dos pesquisados estavam lendo no dia em que foram entrevistados. 14\% também declararam nunca ler. De acordo com os entrevistados, $11 \%$ não lêem por não terem dinheiro para comprar livros. Mas apenas $8 \%$ dos livros lidos foram retirados em bibliotecas, enquanto cerca de metade da população comprou os livros que leu. No entanto, os 
Pela leitura de textos autobiográficos dos escritores citados, podemos perceber que não foi exata e necessariamente a escola a principal formadora desse gosto pelos livros e pela leitura. O objetivo deste artigo é, então, apontar e discutir instâncias formadoras de leitores, na obra $A M S$, tomando como referenciais teóricos alguns conceitos da sociologia da educação, da família e das práticas culturais, como as noções de herança

motivos para o brasileiro se afastar dos livros não se resumem a uma dificuldade de acesso, variam segundo a idade e, principalmente, de acordo com a faixa etária, o grau de escolaridade e a classe social. No cômputo geral, 39\% declararam não ter tempo para a leitura. A pesquisa considerou três dos motivos apontados para não gostar de ler como barreiras concretas: a falta de dinheiro para comprar livros, que atinge 11\%; dificuldades para entender palavras e frases, $10 \%$ (que seriam, segundo os pesquisadores, os chamados analfabetos funcionais); a preferência por outros meios de obtenção de conhecimentos, citada por $8 \%$ dos pesquisados. É importante lembrar que, entre os que lêem, a literatura não está exatamente entre os gêneros mais lembrados. Leitores e leitoras preferiram livros ligados a assuntos religiosos, aí incluída a Bíblia, a qualquer outro tema. Após os assuntos religiosos, aparecem nas estatísticas assuntos como informática, entre os homens (denotando uma preocupação com aprimoramento profissional), e culinária, entre as mulheres. O tipo de leitura que mais se aproxima de uma identificação com uma atividade de lazer é a de quadrinhos, que aparece nos três primeiros lugares para ambos os sexos. Os pesquisadores não souberam precisar, porém, se os entrevistados se referiam a livros ou revistas, pois a resposta foi espontânea, e não escolhida de uma lista sugerida no questionário. Segundo a pesquisa, apenas $20 \%$ dos entrevistados compram livros. Uma parcela considerável (14\%) afirmou não possuir nenhum livro. Apenas 1\% declarou ter uma biblioteca de mais de 500 volumes. Essa pesquisa foi realizada em 49 cidades brasileiras, distribuídas pelas cinco regiões, entre 10 de dezembro de 2000 e 25 de janeiro de 2001, por encomenda de quatro entidades do setor livreiro (Câmara Brasileira do Livro - CBL, Sindicato Nacional dos Editores de Livros - SNEL, Associação Brasileira de Celulose e Papel -Bracelpa e Associação Brasileira dos Editores de Livros - Abrelivros). Em cada região, as cidades foram determinadas por sorteio, bem como foram sorteados os domicílios visitados e, em cada casa, quem seria o entrevistado (desde que fosse alfabetizado, com 14 anos ou mais e escolaridade mínima de três anos). Foram 130 entrevistas em cada cidade, à exceção de São Paulo, que teve 433 entrevistados, por ser considerado o maior mercado editorial brasileiro. O montante de entrevistados 
e transmissão de capital cultural. (Cf., por exemplo, BOURDIEU, 1982 e 1983; DE SINGLY,1996; LAHIRE, 1997; NOGUEIRA, 1997; BATISTA, 1998)

No artigo "Leitura literária e outras leituras", produzido em 1996, mas só publicado em 1999, Regina Zilberman termina com uma pergunta bastante provocativa: "Por que a escola não pode aprender com a literatura, em vez de ensiná-la?"(ZILBERMAN, 1999: 78) Nesse trabalho, inicialmente a pesquisadora traça um histórico sobre a questão da leitura nos livros didáticos e em documentos oficiais. Posteriormente, apresenta posturas a princípio estranhas com relação à leitura - de um trecho de Sócrates (c. 470-399 a. C.), publicado em Fedro, dos Diálogos de Platão, a um trecho de um ensaio intitulado "Sobre livros e leitura", de 1851, de

foi de mais de 4000 pessoas. Dessas, somente 9\% tinham curso superior completo, e a maior parte dos entrevistados, 38\%, vinham da classe C renda familiar mensal de $\mathrm{R} \$ 844,00$, em média, pelo critério usado, da Associação Brasileira de Anunciantes. A classe A, de renda média de $\mathrm{R} \$ 4.818,00$, participou com $7 \% ; 25 \%$ eram da classe $\mathrm{B}$ (renda de $\mathrm{R} \$ 2.029,00$ ); e 30\% vinham das classes D e E (rendas médias de $\mathrm{R} \$ 435,00$ e $\mathrm{R} \$ 229,00$, respectivamente). Projetada sobre o total da população, a amostra representou 86 milhões de possíveis leitores, estimativa baseada no crescimento populacional entre 1996 e 2000.

A pesquisa Indicador Nacional de Alfabetismo Funcional - INAF, de 2001, foi realizada pelo Instituto Paulo Montenegro, instituição criada pelo IBOPE no ano 2000, direcionada para a execução de projetos na área de educação. O INAF 2001 teve como objetivo apurar as habilidades e práticas de letramento da população de jovens e adultos. Para isso, realizou uma entrevista domiciliar com 2.000 pessoas, entre 15 e 64 anos de idade, residentes nos meios urbano e rural de todas as regiões brasileiras. Os resultados do INAF 2001 apontam que, na indicação de tipos de material escrito que possuem em suas residências, o maior número de indicações recaiu sobre registros memorialísticos (álbum de família, fotos) - 89\%; Bíblia, livros sagrados ou religiosos - 86\%; superando de muito o número de indicações de materiais ligados ao letramento escolar - dicionário (65\%) e enciclopédia (35\%) e livro didático (59\%). Os "livros de literatura/romances" recebem apenas 44\%. Quando perguntados sobre os tipos de material que mais gosta de ler para se distrair, os entrevistados responderam: 49\% para revistas; 44\% para jornais; 43\% para Bíblia, livros sagrados ou religiosos; 34\% para livros (de modo geral); não figurando na lista indicações da leitura literária explícita (romances, contos, poemas, etc.). 
Schopenhauer - em que os ilustres filósofos, separados por séculos de história, negam o valor da leitura. Mais à frente, apresenta outros depoimentos de escritores que valorizavam a leitura. Por fim, Zilberman termina por articular esses temas com o caráter emancipatório da literatura, proposto por Jauss na Conferência de Constança, e as idéias Wolfgang Iser, colega de Universidade de Jauss, à época, para quem a natureza da obra literária determina as características da leitura e seus efeitos. Assim, a pesquisadora demonstra por que a leitura e a literatura não constituem disciplinas autônomas na escola, servindo sempre como ponte para se atingir um resultado que está além dela, como o conhecimento de algum conteúdo específico, ou o seu caráter propedêutico: a leitura na escola apenas prenunciava a passagem para a verdadeira literatura, a ser descoberta. Dessa forma, enquanto a escola parece não dar conta de formar leitores, a literatura, ela mesma, consegue formá-los, como demonstra o seguinte depoimento do poeta parnasiano Olavo Bilac:

No colégio, todos nós líamos Júlio Verne; os livros passavam de mão em mão; e, à hora do estudo, no vasto salão de paredes nuas e tristes, enquanto o cônego dormia a sesta na sua vasta poltrona, e enquanto o bedel, que era charadista, passeava distraidamente entre as carteiras, combinando enigmas e logogrifos, - nós mergulhávamos naquele infinito páramo do sonho, e encarnávamos nas personagens aventureiras que o romancista dispersava, arrebatados por uma sede insaciável de perigos e de glórias, pela terra, pelos mares e pelo céu. (BILAC, 1996)

Também o poeta modernista mineiro Carlos Drummond de Andrade, personagem de $A M S$, no poema "Biblioteca Verde", fala das emoções provocadas pela posse dos livros da Biblioteca Internacional de Obras Célebres, comprada pelo seu pai devido à grande insistência do filho:

Chega cheirando a papel novo, mata de pinheiros toda verde. Sou o mais rico menino destas redondezas. (Orgulho, não; inveja de mim mesmo.) Ninguém mais aqui possui a coleção das Obras Célebres. Tenho de ler tudo. Antes de ler, que bom passar a mão no som da percalina, esse cristal de fluida transparência: verde, verde. Amanhã começo a ler. Agora não. [...] 
Mas leio, leio. Em filosofias

tropeço e caio, cavalgo de novo

meu verde livro, em cavalarias

me perco, medievo; em contos, poemas

me vejo viver. Como te devoro,

verde pastagem. Ou antes carruagem

de fugir de mim e me trazer de volta

à casa a qualquer hora num fechar

de páginas? (ANDRADE, 1979)

Na revista Presença pedagógica, Regina Zilberman, ao discutir problemas do ensino de literatura, afirma:

Raras vezes a escola, seu aparato, como salas de aula, seus instrumentos, como o livro didático, e sua metodologia, como a execução do dever de casa, provocam lembranças aprazíveis de leitura. As atividades pedagógicas provocam tédio, quando não são vivenciadas como aprisionamento, controle ou obrigação. A leitura parece ficar do lado de fora, porque os professores não a incorporam ao universo do ensino. Quem lê, contudo, quer o lado de fora, para onde se desloca, comandado pela imaginação. Por isso, talvez seja o caso de se pensar em transformar o 'de dentro' da sala de aula em 'de fora' da leitura. (ZILBERBMAN, 1996)

É ainda Regina Zilberman, no artigo "A criança, o livro e a escola", quem demonstra o procedimento da literatura em relação ao leitor:

Ela sintetiza, por meio dos recursos da ficção, uma realidade, que tem amplos pontos de contato com o que o leitor vive cotidianamente. Assim, por mais exacerbada que seja a fantasia do escritor, ou mais distanciadas e diferentes das circunstâncias de espaço e tempo dentro das quais uma obra é concebida, o sintoma de sua sobrevivência é o fato de que ela continua a se comunicar com o destinatário atual, porque ainda fala de seu mundo, com suas dificuldades e soluções, ajudando-o, pois, a conhecê-lo melhor. (ZILBERMAN, 1981: 12-31)

Está aí novamente o caráter emancipatório da literatura, que tem uma função formadora, que não se confunde com uma missão pedagógica, uma vez que se propõe à tarefa de dar um "conhecimento do mundo e do ser", como sugere Antonio Candido, e não à instrução de boas maneiras, de comportar e ser ou de falar e escrever. ${ }^{5}$

\footnotetext{
${ }^{5}$ Esta questão está discutida em ZILBERMAN, 1981, p. 12-31.
} 
Também Daniel Pennac (1993), no seu ensaio literário Como um romance, relata as suas próprias experiências como professor de Francês e a de outros professores. Pennac diz que incentivava o gosto dos seus alunos pela leitura literária através da leitura oral, em sala de aula, de inícios de romances, sem nenhuma tarefa posterior à leitura, como a produção de fichas ou avaliações. Escutar era tudo o que o professor pedia, à frente dos olhos estupefatos dos alunos que já se preparavam para tomar notas. O exemplo citado é o trabalho com o livro O perfume, de Patrick Süskind. Após essa iniciação, os próprios alunos, descritos pelo ensaísta como pessoas que, no início, mostravam-se totalmente distantes ou até mesmo avessas à literatura, corriam às bibliotecas e livrarias, a fim de encontrarem os livros nos quais foram iniciadas, para lê-los com avidez.

Pennac cita ainda o trabalho do poeta Georges Perros, que também era professor, através do depoimento de uma ex-aluna:

Ele (Perros) chegava desgrenhado pelo vento e pelo frio, em sua moto azul e enferrujada. Encurvado, numa japona azul-marinho, cachimbo na boca ou na mão. Esvaziava uma sacola de livros sobre a mesa. E era a vida. [...] ele puxava um livro, nos olhava, começava com um riso que nos aguçava o paladar e se punha a ler. Ele caminhava, lendo, uma das mãos no bolso, a outra, a que segurava o livro, estendida, como se, lendoo, ele o oferecesse a nós. Todas as suas leituras eram como dádivas. Não nos pedia nada em troca. [...] Por sua voz descobríamos que aquilo tudo tinha sido escrito para nós. Essa descoberta surgia após uma interminável escolaridade em que o ensino das Letras nos havia mantido a uma respeitosa distância dos livros. O que fazia ele a mais do que os nossos professores? Não muito. Sob certos aspectos, fazia mesmo muito menos. Só que não nos entregava a literatura num conta-gotas analítico, ele a servia a nós em copos transbordantes, generosamente... E nós compreendíamos tudo que ele nos lia. Nós o escutávamos. Nenhuma explicação do texto seria mais luminosa do que o som da sua voz quando ele antecipava a intenção do autor, acentuava um subentendido, revelava uma alusão... Ele tornava impossível o contra-senso. ${ }^{6}$

${ }^{6}$ Depoimento de ex-aluna de George Perros, não identificada, citada na biografia do poeta escrita por Jean Marie Gibbal. Não há indicação bibliográfica precisa sobre a obra em questão, devido às características do ensaio de Pennac. Ver PENNAC, 1993, p. 86-87. 
Pennac, que se tornou um escritor de sucesso, com cifras de vendagem de 117 mil exemplares, também professa, corajosamente, um decálogo com os direitos do leitor. Direitos esses que fazem arrepiar os guardiães tradicionais da leitura, mas que tratam de atitudes tomadas provavelmente por uma grande parte daqueles que se consideram "bons leitores" ou "grandes leitores" e que são negadas aos leitores em formação: o direito de não ler; de pular páginas, de não terminar um livro; de reler; de ler qualquer coisa; de se dedicar ao bovarismo; de ler em qualquer lugar; de ler uma frase aqui e outra ali; de ler em voz alta e de se calar. Qual de nós, professores e/ou acadêmicos, não tomou uma dessas atitudes? Quantas vezes abandonamos um livro nas suas primeiras páginas, movidos por um sem-número de razões? Quantas vezes lemos textos de qualidade duvidosa? Quantas vezes folheamos um livro que até mesmo temos em casa sem nunca lê-lo por completo? E não serão essas formas de leitura também legítimas? Não têm o seu valor, quando contextualizadas?

Três instituições são mais importantes na formação de leitores literários: a escola, a família e a própria literatura. Parece que a família e a literatura têm tido maior êxito nessa empreitada, a despeito de algumas bem-sucedidas experiências escolares, é o que parece também comprovar uma leitura de $A M S$, com a intenção de mapear a formação de leitor do seu narrador.

A literatura tem sido usada como fonte em diferentes áreas de estudo, como a Sociologia, a Filosofia, a Psicanálise, a História, dentre outras. Também a Educação tem desenvolvido trabalhos investigativos a partir do texto literário, tomando a literatura como um discurso cultural capaz de fornecer pistas para a construção de uma história da educação e das práticas culturais.

O discurso literário em prosa pode ser dividido em duas grandes vertentes: a chamada narrativa de ficção e a narrativa de memória. Se a literatura de memória é vista como um discurso cultural, pode-se pensar também na memória social de um povo por meio de obras literárias e, se nenhuma memória é exclusiva de um indivíduo e não se mantém impenetrável às lembranças de outros, pode-se pensá-la como social, histórica, cultural, simbólica. Portanto, o texto memorialístico não é constituído apenas pela memória do narrador: é também a memória de um grupo social e cultural, é uma parte da história do mundo. No livro aqui analisado, $A M S$, é possível perceber, em diferentes momentos, que o narrador se vê forçado a fazer digressões sobre a história social e política 
de Santana do Rio Verde (por exemplo, os capítulos "Triunfal chegada do Dr. Valverde" e "Mouros e cristãos cruzam espadas") e de Belo Horizonte (ver, por exemplo, o capítulo que abre a segunda parte do livro, intitulado "Belo Horizonte", e os capítulos "Remata-se o painel", "Velórios, serenatas" e "De como o autor se viu metido na camisa cáqui, dentre outros), para continuar narrando os acontecimentos da sua vida. A literatura de memória é o discurso estetizado do vivenciado e do relembrado. Como se trata de uma elaboração artística a partir do real, a literatura de memória oscila entre a ficção e a realidade. Se, por um lado, é possível recuperar factualmente muito do que é narrado; por outro lado, o narrado constitui uma reinvenção do vivenciado e, portanto, uma forma de ficção. Resta ainda tratar de uma possivel diferença entre a narrativa autobiográfica e a memorialística. Se, para alguns, a diferença entre esses dois gêneros relaciona-se à centralidade da narrativa na vida individual, para a autobiografia, e no contexto sóciohistórico-geográfico ou no coletivo, para a memória, essa distinção parece ser muito mais decorrente de uma subjetividade, devido aos pactos de leitura estabelecidos, ou devido a estratégias metodológicas. Essa questão é tratada por Phillippe Lejeune (1975), em Le pacte autobiografique, e retomada por Wander Melo Miranda (1992), em Corpos escritos, e Maria Helena Palma de Oliveira (2001), em Lembranças do passado: a infância e a adolescência na vida dos escritores brasileiros.

Usar a narrativa autobiográfica/memorialística como fonte de pesquisa para as práticas de letramento pressupõe pensá-la como um documento, mas não se pode esquecer que se trata de um "documento estetizado".

\section{Letramento: implicações para a formação do leitor e do escritor}

O termo letramento designa o processo individual e social de apropriação do mundo da escrita, como uma espécie de continuidade/ ampliação do processo de alfabetização. Os processos de letramento, de maneira geral, e de letramento literário - entendido como a apropriação da tradição literária - têm sido objetos de recentes e relevantes estudos no panorama acadêmico (Ver, por exemplo, Magda Soares, 1998, Letramento: um tema em três gêneros).

Pesquisas quantitativas têm sido realizadas por grandes instituições, a fim de identificar os diferentes níveis de letramento em diversas partes 
do mundo. Podem-se citar, a pesquisa internacional PISA 2000, que teve como objetivo produzir uma nova base para o diálogo entre políticas e para a colaboração na definição e na operacionalização de metas educacionais em diferentes países - por meios inovadores que reflitam julgamentos sobre habilidades relevantes para a vida adulta, e a pesquisa INAF 2001, que teve como objetivo fazer um levantamento nacional sobre o alfabetismo funcional dos jovens e adultos no Brasil, a fim de subsidiar políticas de incentivo à leitura. A essas pesquisas, somam-se investigações de natureza conceitual, que procuram definir conceitos e estabelecer relações entre eles, como a distinção entre os processos de alfabetização e letramento, os diferentes tipos de letramento (funcional, literário, filosófico, digital etc.), as semelhanças e diferenças entre letramento escolar e letramento social, as relações entre letramento e escolarização, dentre outras. Realizam-se, ainda, trabalhos de análise dos dados apresentados pelas pesquisas quantitativas, com abordagem de aspectos educacionais, sociológicos, psicológicos, históricos, dentre outras áreas (ver, por exemplo, diferentes artigos publicados no livro organizado por Vera Masagão Ribeiro, 2003, Letramento no Brasil, a publicação Conbecimentos e atitudes para a vida: resultados do PISA 2000, também de 2003).

Analisar o percurso de formação do escritor Cyro dos Anjos a partir de seu relato memorialístico, mapeando o seu processo de formação de leitor literário, foi o principal objetivo deste trabalho, conforme já foi dito. É também intenção do grupo de pesquisa interdisciplinar que vem se constituindo no Centro Universitário de Belo Horizonte estudar a formação de leitores/escritores a partir de outros relatos autobiográficos/ memorialísticos de escritores e escritoras do Brasil do século XX, a fim de se compor um painel da formação desses intelectuais.

Neste artigo, foram escolhidos dois momentos da narrativa - um na infância e outro da juventude do narrador - para explorar a questão da representação de sua formação de leitor de literatura.

\section{Entre o ouvir e o ler: o início de um letramento literário}

De ouvir histórias da Carochinha, contadas pelo primo Ataualpa, filho de Tia Julinda, o narrador de $A M S$ gostava. Nos três primeiros capítulos do livro, o narrador autodiegético menciona isso três vezes: à 
página 13, quando diz desinteressar-se da conversa à porta da Loja do Pai para poder escutar histórias da Carochinha, contadas pelo primo, que era um "insigne contador", até que Luísa Velha, também ela, contadora de histórias, vinha chamar as crianças para o lava-pés diário, antes de se deitar, na pequena Santana do Rio Verde; à página 15, quando, ao descrever as audições de música que os adultos promoviam nas noites de inverno, o narrador, assumindo a voz de seus companheiros-meninos, menciona: "nós, garotos, exultávamos: assim entretida, a gente adulta nos esquecia, e até mais tarde podíamos ouvir Ataualpa ou prolongar o brinquedo no gramado, ultrapassando o marco inexorável das oito badaladas cruéis, desferidas pela torre do Mercado"; e, por fim, à página 21, quando o narrador compara as histórias maravilhosas contadas por Ataualpa ao "pobre repertório de Luísa Velha". O narrador demonstra todo o seu envolvimento com as histórias ouvidas, dizendo que "certas noites, ele [Ataualpa] judiava, contando a triste morte de D. Ratinho ou as ruindades de Barba-Azul, causa para mim de muito pesadelo. Em compensação, vezes sem conta repetiu-nos as peripécias de Pedro Malasartes e do Botas de Sete Léguas." Ainda nessa mesma página, o narrador menciona, desgostoso, o fato de às vezes Tia Julinda não aparecer a sua casa, "sonegando-nos Ataualpa e seu maravilhoso mundo". Ao lado dessas manifestações de agrado pelas histórias ouvidas do primo, o narrador menciona, já nas primeiras páginas do primeiro capítulo, à página 10: "Só de raro em raro o Pai abria mão dos enfadonhos e intermináveis minutos de leitura. Fazia questão de transmitir ao clã o que achara proveitoso nos livros mandados vir por intermédio de caixeirosviajantes ou adquiridos pessoalmente, na viagem anual ao Rio." Os trechos lidos pelo Pai eram páginas de divulgação científica, discursos de Rui Barbosa no Senado, um ensaio ou uma biografia e até mesmo reflexões filosóficas, como pôde perceber apenas mais tarde, conforme o narrador mesmo diz. Essas leituras, inacessíveis às vezes até aos mais velhos (p. 10), entediavam o narrador e as demais crianças da família. Corroboram, ainda, essa postura do narrador as expressões "malsinada leitura" (p. 10) e a referência a elas como o trecho (assim mesmo, em itálico, na p. 10) lido, dando à palavra um tom pejorativo.

Outra importante referência ao letramento literário do narrador de AMS é o "incipiente prazer estético" (p. 22) experimentado pelo narrador ao ouvir as "ternas cantigas, que diziam de amor e de flores". Esse incipiente prazer estético levava o menino-narrador a prender-se ao 
círculo das cantigas de rodas das meninas, fitando-as enquanto rodavam e cantavam, já que o narrador dessa roda não participava, até mesmo fingia às vezes ignorar, colocando-se de lado, braços cruzados (p. 21), já que "era coisa para meninas". Ainda na mesma página 21, o narrador demonstra sua preocupação com certas palavras, que "davam que pensar": "como teria o rei conseguido matar Crispim, com um frágil ramo de alecrim?", questiona o narrador, ao querer que a poesia servisse à razão. Só mais tarde também descobre o narrador que a poesia está a serviço de um poder maior, e se arroga o direito de forjar um veículo autônomo (p. 21).

\section{Intermináveis noites boêmias de jovens intelectuais}

Em $A M S$, um outro momento importante para a formação de leitor do seu narrador encontra-se na segunda parte do livro, intitulada "Mocidade, amores". O capítulo 14 dessa parte, intitulado "Zeca e Monzeca", trata da convivência do narrador com os poetas que dão título ao capítulo e também das suas relações com os escritores mineiros que formaram o grupo de A Revista, importante veículo de divulgação das idéias e dos trabalhos dos modernistas mineiros da década de 20, como Pedro Nava, Carlos Drummond de Andrade, João Alphonsus e Emílio Moura. Conterrâneos do narrador, Zeca e Monzeca são dois poetas boêmios, um pouco mais velhos que ele, que também migraram para Belo Horizonte. Neste capítulo, o narrador retoma uma discussão travada pelos dois a respeito das relações entre poesia e música. Pela leitura do capítulo, é possível perceber que Zeca e Monzeca não chegaram a publicar seus poemas. O primeiro morreu cedo, com menos de trinta anos, em 1928. O segundo, apesar de doente, viveu até os setenta anos, mas não publicou seus livros. Ao final do capítulo, o narrador filosofa: "Não será absurdo admitir que muitos dos melhores livros estariam entre aqueles que não foram escritos: os que ficaram inéditos, perdidos em tertúlias de bar ou conversas de esquina". (p. 301). O narrador ainda acrescenta:

"Naquela madrugada voltei para casa deslumbrado. Tivera a revelação de que poesia é música, e música é poesia, e toda arte é, afinal poesia e música, se não poesia apenas, que a poesia tudo contém. E não só a arte, pensava, mas também a vida, que só vale em estado de poesia.” (p. 301) 
O capítulo 15, "Entre passadismo e futurismo", também possibilita vislumbrar as leituras de grandes nomes da literatura de língua portuguesa: Machado de Assis e Eça de Queirós. Ao descrever as noitadas no bar Estrela, com os citados poetas Zeca e Monzeca e também com o amigo de infância Newton e o poeta Ari Teo, o narrador aponta a sua predileção por Machado de Assis, de quem diz ser "o reticente, o ambíguo mestre de Dom Casmurro, mais fidedigno, em seus entretons, às contradições da alma, do que o rasgado, o transbordante Eça, cujas páginas todavia me fascinavam pela graça e luminosidade."(p. 302) O amigo Newton, por sua vez, atacava Machado de Assis, repetindo o que lera de um certo crítico: "a gagueira física [de Machado] se lhe estendera à prosa". O narrador retrucava, dizendo que Machado "dizia não dizendo", instaurando a dúvida, deixando a decisão para o leitor. Neste capítulo, o narrador confessa a sua ignorância, à época, a respeito de escritores estrangeiros como Anatole France ou Oscar Wilde, ressalvando as leituras feitas em sua adolescência, em Santana, de Zola e Victor Hugo.

No bar Estrela, os amigos espreitavam o grupo de A Revista, ouvindo as conversas entre Dummond, Nava, João Alphonsus e Emílio Moura, ficando a discutir as conversas e os nomes ouvidos da mesa dos intelectuais: Mário de Andrade, Oswald de Andrade, Manuel Bandeira, ainda pouco conhecidos dos protagonistas de $A M S$.

\section{A literatura como formadora de leitores}

AMS é uma narrativa densa de referências culturais, marcada e influenciada pelas leituras do narrador, que não somente justifica o sujeito de memória, como também retrata, no decorrer da obra, o seu letramento literário, que contribuiu para a sua formação de escritor.

Práticas de leitura - não só literária, mas também filosófica e científica - estão bem presentes na vida familiar do narrador, como se depreende na página 54. Assim, podemos perceber que se trata de um herdeiro cultural, cujo gosto pela leitura foi apropriado pelo menino, a despeito do enfado sentido nos serões. Filho de uma família classe média - um pai comerciante e fazendeiro, culto, que convivia, em sua loja, com juízes, promotores e poeta da cidade, "grande ledor de ensaios filosóficos e literários, conhecedor de latim" e uma mãe "versada em francês e latim" (MENEZES, 1978:55), credenciais que permitem classificá-la como 
detentora de um bom capital cultural-do interior mineiro nas primeiras décadas do século XX, a família Versiani dos Anjos, dentre seus treze filhos, teve também como escritores o médico Valdemar Versiani dos Anjos e o farmacêutico Antônio Versiani dos Anjos, filhos do mesmo Antônio dos Anjos e de Dona Carlota Versiani dos Anjos.

Com relação ao estímulo escolar, o narrador relata, na página 60 , o incentivo literário advindo de um dos seus professores, que o presenteia com uma edição infantil de Os Lusíadas. Já no início de sua vida escolar, o narrador demonstra aptidão para a escrita de textos de gêneros distintos: como a poesia e a notícia redigidas nos jornais manuscritos (página 60), juntamente com os amigos Newton e Rosalvo.

A respeito das qualidades literárias do texto de Cyro dos Anjos, de maneira geral, e de sua literatura memorialística discorrem os ensaístas Antonio Candido e Aderaldo Castello:

Cyro dos Anjos se caracteriza pelo calor esbatido do lirismo e da melancolia, traduzidos por uma frase clássica e moderna, cheia de pudor, compondo um discurso sinuoso que traduz admiravelmente a contida riqueza do seu universo ficcional.

Essas mesmas qualidades aparecem, de modo talvez um pouco guindado, mas com uma elegância e uma justeza perfeitas, no seu livro de memórias da infância e da adolescência, - onde percebemos as raízes da sua melhor novelística. (CANDIDO E CASTELLO, 1979:333)

Por fim, vale lembrar que o letramento literário assinala uma inclusão basicamente de leitura, mas isso não corresponde a um apassivamento do leitor, uma vez que a leitura literária implica a participação do leitor no processo de recriação do texto, através de um fazer tão estético quanto o do autor. Nota-se, então, que o narrador de $A M S$ foi, com o passar dos anos, não somente aprimorando o seu letramento literário, como tomando consciência desse seu ato e se incluindo também no outro lado da arte literária: o daqueles que escrevem, o dos escritores. É possível perceber, através das experiências estéticas do narrador, a sua emancipação. 


\section{Referências Bibliográficas}

ANDRADE, Carlos Drummond de. Obra completa. (Com estudo de Emanuel de Moraes) 5. ed. Rio de Janeiro: Nova Aguilar, 1979.

ANJOS, Cyro dos. A menina do sobrado. (memórias) 2. ed. Rio de Janeiro/ Belo Horizonte: Garnier, 1994. (A primeira edição, com este título, é de José Olympio-INL-MEC e data de 1979).

BATISTA, Antônio Augusto Gomes. A leitura incerta: a relação de professores(as) de Português com a leitura. Educação em revista. Belo Horizonte, n. 27, p. 85-103, jul. 1998.

BILAC, Olavo. Júlio Verne. In: Ironia e piedade. In: - Obra reunida. Organização e introdução: Alexei Bueno. Rio de Janeiro: Nova Aguilar, 1996. p. 726-729.

BOSI, Alfredo. História concisa da literatura brasileira. 35. ed. São Paulo: Cultrix, 1994.

BOURDIEU, Pierre. A economia das trocas simbólicas. São Paulo: Perspectiva, 1982.

BOURDIEU, Pierre. Gostos de classe e estilos de vida. In: ORTIZ, Renato (Org.). Pierre Bourdieu: sociologia. São Paulo: Ática, 1983. p. 82-121.

CANDIDO, Antonio; CASTELLO, J. Aderaldo. Presença da literatura brasileira. Modernismo. São Paulo: Difel, 1979.

COLASANTI, Marina. Que escritor seria eu se não tivesse lido? In: SIMPÓSIO INTERNACIONAL TRANSDISCIPLINAR DE LEITURA, 2000, Rio de Janeiro. Sesc - RJ e Leia Brasil - Programa de Leitura da Petrobrás. 2000. 1 CD-ROM.

Conbecimento e atitudes para a vida: resultados do PISA 2000 - Programa Internacional de Avaliação de Estudantes/OCDE - Organização para a Cooperação e Desenvolvimento Econômicos. São Paulo: Moderna, 2003.

DE SINGLY, François. L'appropriation de l'héritage culturel. Lien social et politiques, n. 35, p. 153-154, printemps 1996.

FONSECA, Maria Nazareth Soares. Condições de produção da leitura literária. Presença pedagógica, v. 6, n. 34, p. 27-35, jul.-ago. 2000.

ISER, Wolfgang. O ato da leitura. Uma teoria do efeito estético. São Paulo: Ed. 34, 1996. 192 p. v. 1.

ISER, Wolfgang. O ato da leitura. Uma teoria do efeito estético. São Paulo: Ed. 34, 1999. 200 p. v. 2. 
JAUSS, Hans Robert. A história da literatura como provocação à teoria literária. São Paulo: Ática, 1994.

LAHIRE, Bernard. Sucesso escolar nos meios populares: as razões do improvável. São Paulo: Ática, 1997.

LEJEUNE, Phillippe. Le pacte autobiographique. Paris: Éditions du Seuil, s/d. (Copyright de 1975)

MACHADO, Ana Maria. De leitora a escritora. In: SIMPÓSIO INTERNACIONAL TRANSDISCIPLINAR DE LEITURA, 2000, Rio de Janeiro. Sesc - RJ e Leia Brasil - Programa de Leitura da Petrobrás. 2000. 1 CD-ROM.

MENEZES, Raimundo. Dicionário literário brasileiro. 2. ed. Rio de Janeiro: Livros Técnicos e Científicos, 1978.

MIRANDA, Wander Melo. Corpos escritos. Belo Horizonte: UFMG, 1992.

NOGUEIRA, Maria Alice. Convertidos e oblatos - um exame da relação classes médias/escola na obra de Pierre Bourdieu. Educação, Sociedade \& Culturas, n. 7, p. 109-129, 1997.

OLIVEIRA, Maria Helena Palma de. Lembranças do passado: a infância e a adolescência na vida de escritores brasileiros. Bragança Paulista: Universidade São Francisco, 2001.

PENNAC, Daniel. Como um romance. Rio de Janeiro: Rocco, 1993.

PROUST, Marcel. Sobre a leitura. Campinas, SP: Pontes, 1991.

RIBEIRO, Vera Masagão (Org.). Letramento no Brasil. Reflexões a partir do INAF 2001. São Paulo: Global, 2003.

SOARES, Magda. Letramento: um tema em três gêneros. Belo Horizonte: Autêntica, 1998.

ZILBERMAN, Regina. Escritores leitores. Presença pedagógica. Belo Horizonte: Dimensão: v. 2, n. 12., nov./dez. 1996.

ZILBERMAN, Regina. A literatura infantil na escola. 10. ed. São Paulo: Global, 1998. 118 p. ( $1^{\text {a }}$ ed. 1981)

ZILBERMAN, Regina. Leitura literária e outras leituras. In: BATISTA, Antônio Augusto Gomes; GALVÃO, Ana Maria de Oliveira (Org.). Leitura: práticas, impressos, letramentos. Belo Horizonte: Autêntica, 1999. p. 71-88. 


\section{Resumo}

Este artigo tem como objetivo discutir a questão da formação do leitor literário (letramento literário) a partir da narrativa memorialística $A$ menina do sobrado, de Cyro dos Anjos (1906-1994). Procuramos identificar os papéis da família, da escola e da própria literatura na formação do leitor e do escritor. Como referenciais teóricos, foram utilizados conceitos como os de capital e herança culturais, oriundos da sociologia da educação, e de emancipação e experiência estética, da estética da recepção.

\section{Résumé}

Cet article a pour but d'étudier la formation du lecteur littéraire (littéracie littéraire) à partir du récit mémorialiste de A menina do sobrado, de Cyro dos Anjos (1906-1994). On a cherché à identifier le rôle de la famille, de l'école et de la littérature elle-même pour la formation du lecteur et de l'écrivain. Comme supports théoriques on a pris de conceptes tels que ceux du capital et de l'héritage culturels, développés par la sociologie de l'éducation, et ceux de l'émancipation et expérience esthétique, développés par l'esthétique de la réception. 